\title{
Additional information about a mange outbreak by Allopsoroptoides galli (Acari: Psoroptoididae) in commercial laying hens in the state of São Paulo, Brazil ${ }^{1}$
}

\author{
Edna C. Tucci², Nilce M. Soares ${ }^{3}$, João Luiz H. Faccini ${ }^{4 *}$ and David Vilas Boas ${ }^{5}$
}

\begin{abstract}
Tucci E.C., Soares N.M., Faccini J.L.H. \& Vilas Boas D. 2014. Additional information about an outbreak by Allopsoroptoides galli (Acari: Psoroptoididae) in commercial laying hens in the state of São Paulo, Brazil. Pesquisa Veterinária Brasileira 34(8):760-762. Laboratório de Parasitologia, Instituto Biológico, Av. Conselheiro Rodrigues Alves 1252, São Paulo, SP 04014-002, Brazil. E-mail: tucci@biologico.sp.gov.br

This paper reports additional information about a mange outbreak by the mite Allopsoroptoides galli in a commercial egg-laying hen facility in the state of São Paulo, Brazil. About half of the 76,000 multi-age birds of the flock were affected. Experimental infestations carried out on naive hens resulted in clinical signs similar to those diagnosed in naturally infested hens, such as generalized scaly dermatitis, presence of mucus-like material and yellowish crusts on the skin and around the calami, feather loss and strong unpleasant odor. About 30\% drop of egg production was estimated. The possible source of infestation were wild birds identified on the ground and roofs of the sheds.
\end{abstract}

INDEX TERMS: Mange, Allopsoroptoides galli, Psoroptoididae, Acari, dermatitis, commercial flock, chicken.

RESUMO.- [Informação adicional sobre um surto de sarna causado por Allopsoroptoides galli (Acari: Psoroptoididae) em uma granja de poedeiras no Estado de São Paulo.] Este artigo acrescenta informações adicionais sobre um surto de sarna causado por Allopsoroptoides galli em uma instalação comercial de galinhas de postura no estado de São Paulo, Brasil. Approximadamente metade das 76.000 aves, com várias idades, mantidas em uma granja, foram infestadas. Um total de 12 galinhas sem prévio contato com os ácaros e infestadas experimentalmente apresentaram sinais clínicos semelhantes aos diagnosticados em galinhas naturalmente infestadas, tais como dermatite escamosa generalizada, presença de material mucoso, crostas amareladas na pele e em torno dos câlamos, perda

\footnotetext{
${ }^{1}$ Received on July 18, 2014.

Accepted for publication on August 6, 2014.

${ }^{2}$ Laboratório de Parasitologia, Instituto Biológico, Av. Conselheiro Rodrigues Alves 1252, Vila Clementino, São Paulo, SP 04014-002, Brasil.

${ }^{3}$ Unidade de Pesquisa e Desenvolvimento de Bastos, Instituto Biológico, Av. Gaspar Ricardo 1700, Bastos, SP 16.60-000, Brazil.

${ }^{4}$ Departamento de Parasitologia Animal, Instituto de Veterinária, Universidade Federal Rural do Rio de Janeiro (UFRRJ), Seropédica, RJ 23890000, Brazil. Fellow of CNPq. *Corresponding author: faccinijlh@globo.com

${ }^{5}$ Departamento de Biologia Animal, Instituto de Biologia, Universidade Estadual de Campinas, (Unicamp), Rua Monteiro Lobato 255, Campinas, SP 13083-862, Brazil.
}

de penas e forte odor desagradável. A perda na produçãode ovos foi estimada em $30 \%$. As possíveis fontes de infestação foram aves silvestres observadas no chão próximo aos galpões e telhados.

TERMOS DE INEXAÇÃO: Sarna, Allopsoroptoides galli, Psoroptoididae, Acari, dermatite, granja comercial, galinhas.

\section{INTRODUCTION}

There are about 2,500 species of mites associated with birds, occupying all possible habitats of the body, feathers and nests of the hosts (Proctor \& Owens 2000). Species classified in the suborder Acaridida (= Astigmata) and known as feather mites and mange mites cause lesions on the skin, feather follicles and calami of several species of birds such as Epidermoptidae (Kirsten et al. 2001) but this condition is more commonly found among birds in captivity than wild birds. Several species of mites also cause mange and feathers damage in farm yard chickens but such infestations have decreased with the intensification of the poultry industry worldwide. Nonetheless, two blood sucking species, the poultry red mite Dermanyssus gallinae (Dermanyssidae) and the northern fowl mite Ornithonyssus sylviarum (Macronyssidae), are economically important mites in commercial poultry facilities worldwide, including Brazil (Tucci et al.1996). 
In Brazil, the earliest records of mites associated with mange in domestic chicken go back to the 1930s and most of the reports were from farmyard chicken. Vaz (1935) recorded Rivoltasia bifurcata and Epidermoptes bilobatus (Epidermoptidae) in the state of São Paulo, Hipolito \& Freitas (1943) reported E.bilobatus on young birds in the state of Minas Gerais, causing a condition denominated pseudo-mange and characterized by areas of feather loss and slight epithelial desquamation and Reis (1939) and Faccini et al. (1991) reported cases of mange caused by Knemidokoptes mutans (Knemidokoptidae). In addition, Reis \& Nobrega (1956) found only two cases of mange associated with E. bilobatus out of 2,066 necropsies carried out on several species of birds without mentioning the origin of chickens either from farmyard or from commercial production.

In the 1950s the commercial egg-laying facilities began to be implemented in Brazil. Since then, Tucci et al.(2005) reported the occurrence of an mange outbreak by Megninia ginglymura and M. cubitalis in a commercial egg-laying facility in the city of Ourinhos, located approximately 190 $\mathrm{km}$ far from the city of Bastos, state of São Paulo, with a reduction of egg laying by as much as $20 \%$. Recently Mironov (2013) described Allopsoroptoides galli from a mange outbreak in commercial egg-laying that occurred in the city of Bastos, São Paulo state and Buim et al (2013) addressed the findings of microscopic skin lesions and blood alterations in naturally infested birds from the same outbreak.

This paper reports additional information on clinical signs, experimental transmission and possible source of infestation from wild birds for A. galli from the same outbreak.

\section{MATERIALS AND METHODS}

The egg laying flock from the city of Bastos $\left(21^{\circ} 56^{\prime} 15^{\prime \prime}\right.$, $50^{\circ} 41^{\prime} 15^{\prime \prime} \mathrm{W}$ ) represents about $20 \%$ of the national flock. The outbreak occurred in December, 2010 in one commercial egg-laying facility with 76,000 multi-age birds which was comprised of conventional California-style sheds, with two rows of cages on each side harboring two to three hens per cage and a capacity for 3,800 hens per shed. During investigation of the outbreak, several hens were examined clinically and mite samples were collected through skin scrapings in areas with signs of feather loss, crusts and presence of mucus-like material.

A sample of mites was sent to Dr.Sergey V. Mironov of the Zoological Institute of the Russian Academy of Science for identification resulting in the description of Allopsoroptoides galli (Mironov 2013).

In addition, 12 naïve hens from an animal experimental facility at the laboratory of the Biological Institute (IB) in the state of São Paulo were placed in contact with parasitized birds at a 1:1 ratio. Clinical monitoring of the pairs was carried out for five weeks and subsequent skin scrapings were performed for mite diagnosis.

A survey of the bird fauna around the infested facility and other egg-laying facilities in the city of Bastos was also conducted by photographing birds on the ground near facilities and roofs of sheds. The identification of these birds was conducted by the ornithologist Dr. Hermes R. Luz (Department of Animal Parasitology, Universidade FederalRural do Rio de Janeiro, Brazil).

The experimental protocol used in this research was submitted to the Ethics Committee on Experimentation Animal - CETEA-IB and approved on March 23, 2011, protocol number 111/2011.

\section{RESULTS}

Approximately half of the hens in the poultry facility were parasitized by Allopsoroptoides galli. Figure 1A,B displays the male and female mites, respectively.

The clinical examination revealed generalized scaly dermatitis with mucus-like material and yellowish crusts on the skin and around the calami (Fig.2A,B). Areas of feather loss were seen and a strong unpleasant odor throughout the body was also smelled. Lesions were more pronounced under the wings (Fig.2B). Close examination of the skin and feathers revealed thousands of mites on the surface of the

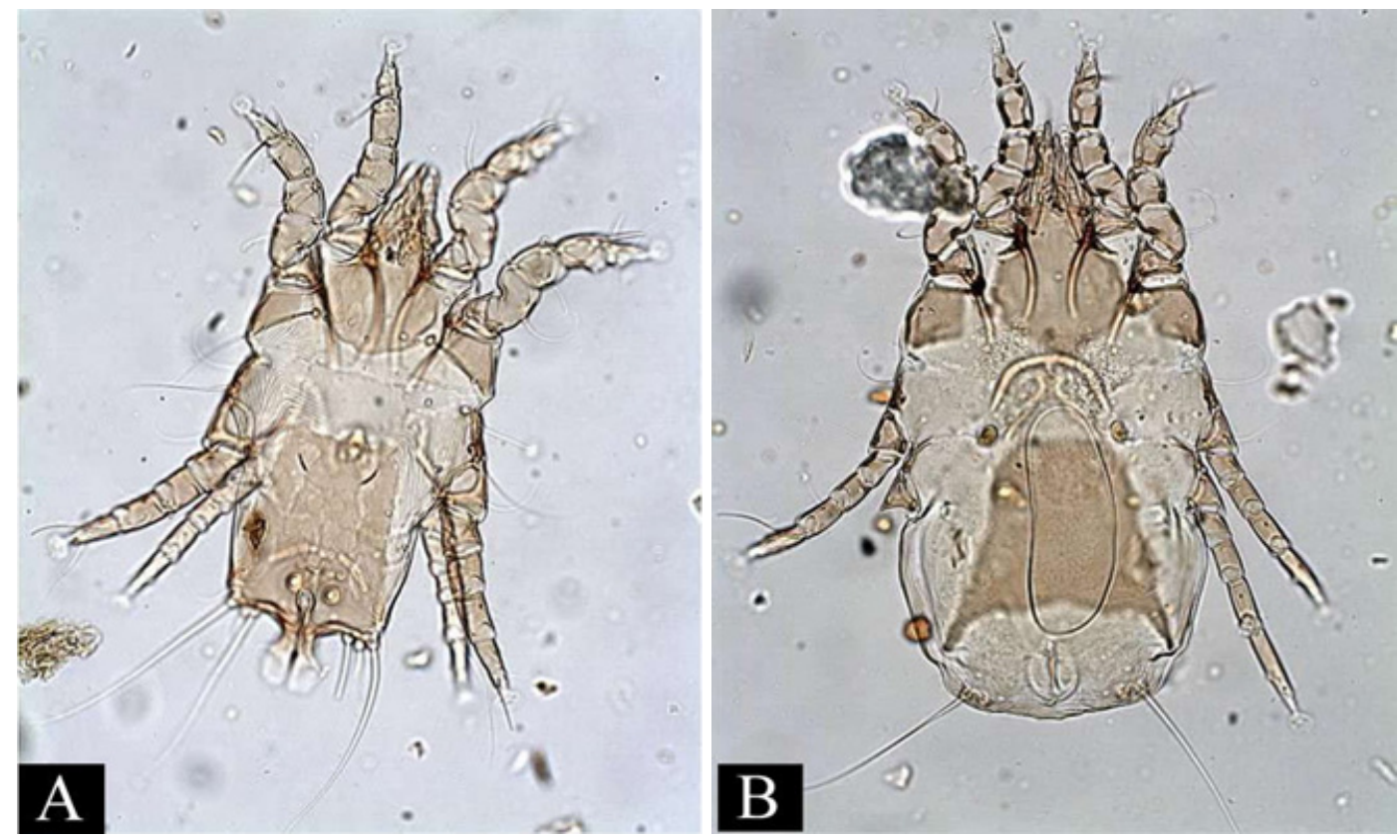

Fig.1. (A) Male, and (B) female of Allopsoptoides galli. Not to scale. 

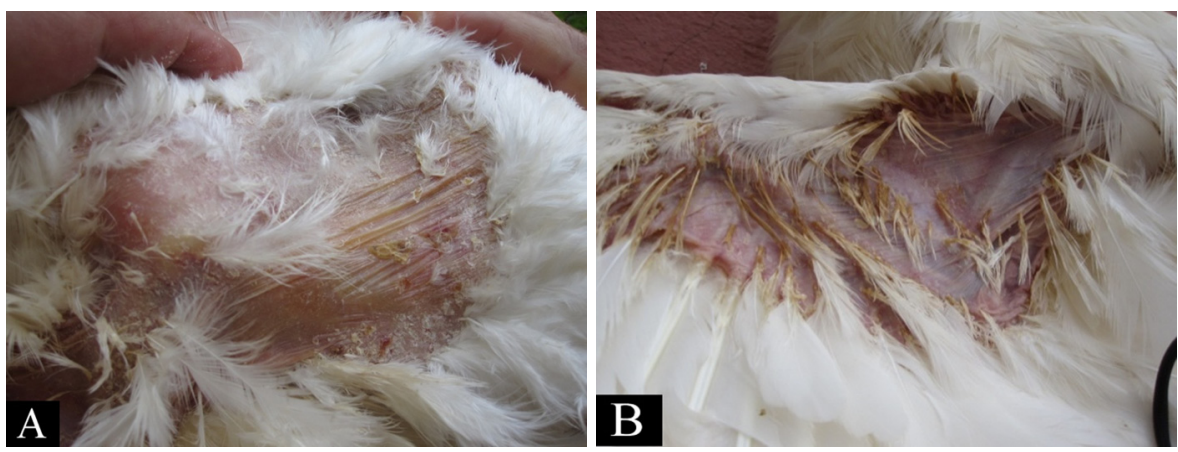

Fig.2. (A) Dermatitis by Allopsoroptoides galli on the chest, and (B) under the wing.

skin, mainly at the base of the feathers, but without deep penetration into the follicle. Reduced feed conversion, weight loss and approximately 30\% dropping egg production were estimated in infested sheds.

The experimental transmission of $A$. galli to naive hens placed in contact with infested hens in the laboratory occurred rapidly through direct contact. All the 12 naive hens exhibited intense itching seven days after initial contact and the first signs of skin desquamation appeared after 15 days. They also became very nervous,scratching themselves intensely and constantly.Skin scrapings also revealed the presence of hundreds $A$. galli associated with lesions.

The following wild birds were identified: Dendrocygna viduata(Anatidae), Bubulcus ibis (Ardeidae), Columba livia (Columbidae), Theristicus caudatus (Threskiornithidae), Caracara plancus (Falconidae), Amazonetta brasiliensis (Anatidae), Ardea alba (Ardeidae), Phalacrocorax brasilianus (Phalacrocoracidae), Gallinula galeata (Rallidae), Anhinga anhinga (Anhingidae), Patagioenas plúmbea (Columbidae),Crotophaga ani (Cuculidae), Passer domesticus (Passeridae), Sarcoramphus papa (Cathartidae) and Columbina talpacoti (Columbidae).

\section{DISCUSSION}

In nature, feather mites are commonly found in several species of birds without associated lesions. As direct contact is the most common mode of transmission among feather mites, it is possible that A. galli was transferred to the facility by wild birds which were identified during visits to the several poultry facilities in the Bastos city area. It is worth mentioning that Allopsoroptoides galli belongs to a group of mites classified in the Pandalurinae (Psoroptoididae) which is associated with some of identified wild birds (Gaud \& Atyeo 1996). If this hypothesis is correct, the population of A. galli might have increased rapidly due to the close contact among the hens in the sheds as seen in all 12 experimentally infested hens in which the first signs of skin desquamation appeared after 15 days. In addition, it is notorious that the defenses of hens at commercial egg-laying facilities are diminished by beak trimming, lack of contact with sun and soil and other stressful situations, making these birds more susceptible to pathogenic agents than would normally occur in nature or farmyard operations (Brown 1972).

The clinical signs seen in the experimentally infested hens were identical to those seen in naturally infested ones (Fig.2A,B). In both situations they were similar to those ob- served in infestations by the feather mites Megninia sp. as reported by Tucci et al. (2005). Moreover, stress resulting from mite infestation is quite intense as seen in experimental infested birds and might be the cause of reduced food consumption and reduced egg laying.

The 20\% dropping in egg production seen in infestations by both species of Megninia (Tucci et al. 2005) as compared with approximately $30 \%$ estimated in infestation by $A$. galli are high, resulting in substantial economic losses that increased with disposal of infested birds and the labor to do so.

\section{REFERENCES}

Brown N.S. 1972. The effect of host beak condition on the size of Menacanthus stramineus population of domestic chickens. Poult. Sci. 51:162-164.

Buim M.R., Leffer A.M.C., Fava C., Spinosa H.S., Bueno R.S. \& Górniak S.L. 2013. The first report about Allopsoroptoides galli n.g., n.sp (sic) Acari: Analgoidea: Psoroptoididae) infected (sic) layer hens: hematological, serum chemistry, and histopathologic findings. Int. J. Poultry Sci. $12: 261-263$

Faccini J.L.H. \& Leite R.C. 1991. Sobre três casos de parasitismo por ácaros. Arq. Univ. Fed. Rural Rio de Janeiro 14:97-100.

Gaud J. \& Atyeo W.T. 1996. Feather mites of the world (Acarina, Astigmata): the supra especific taxa. Annales Sciences Zoologiques, Musée Royale de l'Afrique Central, 277(1):1:1-193, and (2):1-436.

Hipólito O. \& Freitas M.G. 1943. Notas ornitopatológicas: observações sobre alguns acarinos parasitos de Gallus gallus domesticus, em Minas Gerais. Arq. Esc. Sup. Vet., Belo Horizonte, 1:81-82.

Kirsten V.K., Gilardi J.D., Gilardi A.F., Goff M.L. \& Boyce W.M. 2001. Epidermoptid mange in laysan albatross fledglings in Hawaii. J. Wildl. Dis. 37:185-188.

Mironov S.E. 2013. Allopsoroptoides galli n.g., n.sp., a new genus and species of feather mites (Acari:Analgoidea: Psoroptoididae) causing mange in commercially raised domestic chicken in Brazil. Syst. Parasitol. 85:201-212.

Proctor H. \& Owens I. 2000. Mites and Birds: diversity, parasitism and coevolution. Tree 15:358-364.

Reis J. 1939. Alguns parasitos de G. gallus (L.) verificados em São Paulo. Arqs Inst. Biológico, São Paulo, 10:147-153.

Reis J. \& Nóbrega P. 1956. Tratado de Doenças de Aves. Vol.3. Melhoramentos, São Paulo. 318p.

Tucci E.C., Guimarães J.H., Bruno T.V., Gama N.M.S.Q. \& Santos A.M.M. 1996. Ocorrência de ácaros hematófagos em aviários de postura no Estado de São Paulo, Brasil. Revta Bras. Parasitol. Vet. 5:95-102.

Tucci E.C., Guastali E.A.L., Gama N.M.S.Q., Rebouças M.M. \& Mendes M.C. 2005. Infestação por Megninia spp. em criação industrial de aves produtoras de ovos para consumo. Arqs Inst. Biológico, São Paulo, 72:121-124.

Vaz Z. 1935. Ectoparasitas de animais domésticos observados no Estado de São Paulo. Arqs. Inst. Biológico, São Paulo, 6: 29-33. 